\title{
Toxicity Screening of Mouthwashes in the Pollen Tube Growth Test: Safety Assessment of Recommended Dilutions
}

\author{
Udo KRISTEN ${ }^{1}$ \\ Reinhard E. FRIEDRICH ${ }^{2}$ \\ ${ }^{1}$ Institute of General Botany, University of Hamburg, Hamburg, Germany \\ ${ }^{2}$ Department of Oral and Maxillofacial Surgery, Eppendorf University Hospital, Hamburg, Germany
}

\begin{abstract}
This study investigated whether mouthwash dilutions, recommended by the manufacturers, may contribute to oral mucosa irritation. Twenty frequently used mouthwash brands were examined by the pollen tube growth test, an alternative in vitro method for assessment of the irritating potential of ingredients of cosmetic formulations. The test is based on the photometric quantification of pollen tube growth inhibition. This parameter is expressed by $\mathrm{IC}_{50}$ values that characterize the cytotoxic potential of a product. The $\mathrm{IC}_{50} \mathrm{~S}$ clearly revealed that none of the tested mouthwashes should cause acute irritation if used in the recommended dilution. However, at least 4 of the mouthwashes evaluated in this study could probably irritate the oral mucosa acutely if used undiluted (original concentration).
\end{abstract}

Key Words: mouthwash, cytotoxicity, pollen tube growth test, in vitro toxicity.

\section{INTRODUCTION}

The use of mouthwashes with high ethanol content has frequently been linked to an increased risk of oral mucosal ulceration and cancer $(1,2)$. It has been shown that extensive mouthwash use might cause significantly more mucosal irritation in smokers than in non-smokers (3). Several constituents of tobacco smoke are known to be genotoxic thus causing chromosome aberrations and DNA damages $(4,5)$, whereas alcohol has been recognized to severely irritate mucous surfaces of the mouth (6). Both together, acute genotoxic action and chronic irritation fit well into the model of chemical cancer initiation and progression at cellular level (7). The ethanol contents of several brands of mouthwashes equal or exceed those of alcoholic beverages (8). Other irritants, e.g. terpenes, terpenoids and surfactants are additionally present in many mouthwashes as effective ingredients (8). Alcohols and surface-active substances, especially tensides are known to interfere with cellular membranes by disrupting their lipid bilayer, thus causing breakdown of ion gradients normally maintained across the plasma membranes (9). It is likely that in addition to ethanol various other constituents of mouthwashes are candidates to interfere, for example, with the plasma membrane of oral squamous cells and to cause irritation by this mode of action.

It is nearly impossible to examine the toxic effects of a particular formulation on oral mucosa, determine its mutagenic and/or irritating risks and discern between various possible cellular targets of the toxic action because this tissue has to withstand an uncounted number of toxic substances (10).

In addition to the controversial discussion regarding the hazard potential of mouthwashes, there is a high public interest in providing methods that are suited to assess cytotoxicity by routine use and avoid painful animal testing. Several in vitro alternatives to the in vivo assays for examination of irritants applied topically to the skin and mucous membranes of rabbits

Correspondence: Prof. Dr. R. E. Friedrich, Maxillofacial Surgery, Eppendorf University Hospital, University of Hamburg, Martinistr. 22, D-22046 Hamburg, Germany. Tel: +49-40-42803-3259. Fax: +49-430-42803-8120. e-mail: rfriedri@uke.uni-hamburg.de 
have been summarized (11).

This paper describes a more suitable approach to the assessment of possible mouthwash toxicity. In a previous study, we presented results on the cytotoxicity of 9 undiluted mouthwashes (12). These results did not take into account that dilutions of the samples would reduce their irritation potential. Therefore, the present work focused on the safety assessment of 20 mouthwash dilutions recommended by the manufacturers.

\section{MATERIAL AND METHODS}

Mouthwash Brands and Dilutions. Nineteen commercially available mouthwashes were bought in drugstores, and one mouthwash formulation (UKEKonzentrat) was obtained from the EppendorfUniversity Hospital of Hamburg, Germany. The product tradenames are listed in Table 1. Most of the mouthwash manufacturers recommended dilution of their products before use by addition of 3 to 5 squirts of the concentrated mouthwash to a half glass of water. To standardize this vague information, 4 squirts (i.e. approximately $1 \mathrm{~mL}$ ) were diluted in $100 \mathrm{~mL}$ of distilled water (i.e. approximately half glass). Thus, the dilution factor was approximately 100 for most brands. For the brand One Drop Only, the dilution factor was 200 because the manufacturer recommended 1 to 3 drops per $100 \mathrm{~mL}$ (i.e. $0.5 \mathrm{~mL}$ per $100 \mathrm{~mL}$ of water). For the brands, Lacalut and El-ce-med as well as for the UKE formulation, no recommendation was given.

One mouthwash (Regadent med) was waterinsoluble. Therefore, it had to be dissolved in dimethylsulfoxide (DMSO), and then diluted in distilled water to create a concentration series that did not exceed $1 \%$ DMSO in the final concentration used for the PTG test procedure. One percent DMSO was shown to have no influence on pollen germination and pollen tube growth (13). For all tested brands, the standard recommended mouthwash dilutions and the 100\% product concentrations in distilled water were used as

Table 1. Comparison of PTG test data of undiluted and diluted mouthwashes.

\begin{tabular}{|c|c|c|c|}
\hline \multirow[t]{2}{*}{ Product name/ Manufacturer } & \multirow{2}{*}{$\frac{\text { Undiluted product }}{\mathrm{IC}_{50} \text { values }\left(\mathrm{mg} \mathrm{l}^{-1}\right)}$} & \multicolumn{2}{|c|}{ Recommended dilution } \\
\hline & & Dilution factor & $\mathrm{IC}_{50}$ values $\left(\mathrm{mg} \mathrm{l}^{-1}\right)$ \\
\hline 1. Meridol (Wybert, Loerrach, Germany) & $49326 \pm 4881$ & 1 & $49326 \pm 4881$ \\
\hline 2. Weleda (Heilmittel- Betriebe, Schwaebisch, Gmuend, Germany) & $5183 \pm 712$ & 100 & $>100000$ \\
\hline 3. One Drop Only (Odol, Berlin, Germany) & $4857 \pm 687$ & 200 & $>150000$ \\
\hline 4. Odol (Lingner \& Fischer, Buehl, Germany) & $4762 \pm 1085$ & 100 & $>100000$ \\
\hline 5. Dontor (NA) & $4257 \pm 862$ & 100 & $>100000$ \\
\hline 6. Lacalut (Klosterfrau, Cologne, Germany) & $3999 \pm 928$ & NA & -- \\
\hline 7. Dentagard (Colgate-Palmolive, Hamburg, Germany) & $3931 \pm 957$ & 100 & $>100000$ \\
\hline 8. Silident (Huebner, Ehrenkirchen, Germany) & $3868 \pm 1024$ & 100 & $>100000$ \\
\hline 9. Odol extrafresh (Ligner \& Fischer, Buehl, Germany) & $3542 \pm 531$ & 100 & $>100000$ \\
\hline 10. Regadont med (Gold- hand, Duesseldorf, Germany) & $3005 \pm 61$ & 100 & $>100000$ \\
\hline 11. UKE-Konzentrat (University Hospital, Hamburg, Germany) & $1835 \pm 311$ & NA & -- \\
\hline 12. Signal (Elda \& Fabergé, Hamburg, Germany) & $1331 \pm 258$ & 100 & $48284 \pm 3051$ \\
\hline 13. Vademecum (Henkel, Duesseldorf, Germany) & $1156 \pm 353$ & 100 & $34418 \pm 2444$ \\
\hline 14. El-ce-med (Dental-Kosmetik, Dresden, Germany) & $1041 \pm 82$ & NA & -- \\
\hline 15. Perlweiss (Murnauer Markenvertrieb, Murnau, Germany) & $1027 \pm 218$ & 100 & $31905 \pm 3378$ \\
\hline 16. Blendax fresh (Blendax, Mainz, Germany) & $963 \pm 95$ & 100 & $27116 \pm 2813$ \\
\hline 17. Kukident (Hoffman's Staerkefabriken, Bad Salzuflen, Germany) & $915 \pm 70$ & 100 & $28136 \pm 2625$ \\
\hline 18. Paradontax (block drug comp., Ratingen, Germany) & $872 \pm 74$ & 100 & $26292 \pm 2119$ \\
\hline 19. Aronal (Wybert, Loerrach, Germany) & $847 \pm 285$ & 100 & $12689 \pm 3226$ \\
\hline 20. Thera-med liquid (Schwarzkopf \& Henkel, Duesseldorf, Germany) & $541 \pm 131$ & 50 & $6213 \pm 725$ \\
\hline
\end{tabular}

Mouthwash dilutions were performed according to the manufacturers' recommendations. $\mathrm{IC}_{50}$ values listed in this table are the means of $9 \mathrm{IC}_{50}$ s obtained separately from each concentration. $\mathrm{NA}=$ not available. 
stock solutions, from which series of defined concentrations were prepared for the pollen tube growth (PTG) test. These concentrations were 200, 100, 50, $25,12.5,6.25$ and $3.125 \mathrm{~g} \mathrm{l}^{-1}$.

PTG Test Procedure. The pollen used for the PTG test was collected from partially opened flowers of field-grown Nicotiana sylvestris (Spegazz. and Comes) plants. Pollen was stored at $-18^{\circ} \mathrm{C}$, and suspended at a density of $0.5 \mathrm{mg}$ pollen per $0.1 \mathrm{~mL}$ aqueous culture medium for the experiments. The medium consisted of double-distilled water containing $10 \%$ sucrose, $0.01 \%$ boric acid and $3 \mathrm{mM}$ calcium nitrate, buffered with 10 $\mathrm{mM}$ 2-(N-morpholino)-ethanesulfonic acid (MES), adjusted to $\mathrm{pH} 5.6$ with $\mathrm{KOH}$. The experiments were conducted in $50 \mathrm{~mL}$ screw-capped Schott-Duran flasks (Schott, Mainz, Germany), each containing $100 \mu \mathrm{L}$ of the pollen suspension. Then, $100 \mu \mathrm{L}$ of each of the seven different dilutions from each stock solution, according to the seven concentrations mentioned above, were added to the pollen suspensions, to yield final concentrations of $100,50,25,12.5,6.25,3.125$ and $1.56 \mathrm{~g} \mathrm{l}^{-1}$. For the control, $100 \mu \mathrm{L}$ of pure distilled water was added to $100 \mu \mathrm{L}$ of pollen suspension. For the zerotime control, germination of pollen was blocked by addition of $40 \%$ ethanol to the pollen suspension. The suspensions were incubated for $18 \mathrm{~h}$ at $25^{\circ} \mathrm{C}$ to permit pollen germination and tube growth. After incubation, the suspension in each Schott-Duran flask (Schott) was centrifuged at $1000 \mathrm{~g}$ for $1 \mathrm{~min}$, and the pellets were stained with $0.05 \%$ aqueous Alcian blue $8 \mathrm{GX}$ (Sigma, St Louis, MO, USA), freshly prepared from $0.5 \%$ ethanolic Alcian blue stock solution. Surplus dye was removed by washing with distilled water, following aspiration of the supernatant. Dye that bound to the water-insoluble polysaccharides of the pollen tube walls was redissolved by the addition of $40 \%$ citric acid. After further centrifugation, the Alcian blue concentration in the supernatant was measured photometrically at $618 \mathrm{~nm}$ in a Beckman photometer (Beckman Coulter, Fullerton, CA, USA).

The extinctions of test and control experiments were corrected by the zero-time control values before percentage growth inhibition was calculated. Each experiment was independently repeated at least three times, and each concentration group was assayed in triplicate. Thus, at least $9 \mathrm{IC}_{50}$ values were determined for each mouthwash. The plot of the percentage growth inhibition values against the logarithmic scale of the test concentrations produced a concentration-response curve. The $\mathrm{IC}_{50}$ value was calculated from at least 3 curves, by interpolation from the data of the two concentrations defining the $\mathrm{IC}_{50}$ point. The formula used for calculation of the $\mathrm{IC}_{50}$ values was as follows: $\mathrm{IC}_{50}={ }_{\mathrm{e}}\left\{\left[\left(\ln C_{2}-\ln C_{1}\right)\left(50-\mathrm{I}_{1}\right) /\left(\mathrm{I}_{2}-\mathrm{I}_{1}\right)\right]+\ln \mathrm{C}_{1}\right\}$, where $\mathrm{C}_{1}$ and $\mathrm{C}_{2}$ are the concentrations that caused growth inhibition just below or above $50 \%$, respectively. $\mathrm{I}_{1}$ and $I_{2}$ are the percent growth inhibitions for $C_{1}$ or $C_{2}$, respectively. Details of the test procedure have been described previously (13).

\section{RESULTS}

Data from PTG testing of 20 brands of mouthwashes are summarized in Table 1 as $\mathrm{IC}_{50}$ values in an increasing order of cytotoxic potential (it is valid only for the concentrated product and not for the dilutions recommended by the manufacturer). Therefore, Table 1 contains two sets of cytotoxicity data: one is based on the pure mouthwashes and the other on the recommended mouthwash dilutions.

Both data sets show a broad range of inhibitory effects between Meridol at one end and Thera-med liquid at the other. There is also a large difference in the standard deviations of the $\mathrm{IC}_{50}$ values for the tested mouthwash brands. The lowest standard deviation was found for Regadent med (2\%) and the highest for Aronal (33.6\%) and its diluted form (25.4\%). The significance of the differences between the mean $\mathrm{IC}_{50}$ values was calculated using the LSD (last significant differences) test (14), and was found to be sufficient even for those brands producing high standard deviations.

For the first 10 mouthwashes listed in Table 1 (except for Meridol and Lacalut), the PTG test was not able to approximate the $\mathrm{IC}_{50}$ values, due to the extremely low inhibitory effect of the recommended dilutions of these brands. It is worthy mentioning that all tested mouthwashes produced milky emulsions after dilution.

\section{DISCUSSION}

The PTG test was able to evaluate all 20 mouthwash brands without limitations. Comparison of the commercial trade concentrations and the recommended mouthwash dilutions partially revealed large differences among $\mathrm{IC}_{50}$ values even in consideration of the dilution factors. These unexpected differences 
probably resulted from the fact that dilution of the mouthwashes produced milky and highly turbid fluids indicating changes from clear alcoholic solutions to oil/ water emulsions. It has been observed earlier that the response of various in vitro toxicity tests is different to oil/water formulations than to hydro-alcoholic formulations $(15,16)$. This is also true for the PTG test, which showed high sensitivity and prediction capability to emulsions but relatively low ones to hydro-alcoholic solutions of oils (17).

For safety assessment, only the $\mathrm{IC}_{50}$ values of the standard, recommended user concentrations (as far as available) were considered. These values differed from each other in a wide range from more than 150000 $\mathrm{mg} \mathrm{l}^{-1}$ for One Drop Only to $6213 \mathrm{mg} \mathrm{l}^{-1}$ for Thera-med liquid. These differences do not result from various contents of alcohol because the recommended dilutions reduce the alcohol concentration to less than $1 \%$, which does not inhibit pollen tube growth at all. Therefore, different types and amounts of mouthwash ingredients must be responsible for the diverging effects.

Considering the recommended dilutions, none of the tested mouthwashes would produce any acute irritation because their $\mathrm{IC}_{50}$ values are far below of those determined for irritating hydro-alcoholic formulations and oil/water emulsions of cosmetic products $(15,16)$. Even the brand Thera-med liquid, which showed the lowest $\mathrm{IC}_{50}$ value (strongest growth inhibition), is below the level of acute irritation.

It may be possible that long-term exposition to subacute irritant concentrations of a genotoxically altered mucosa cell could enhance tumor formation, as suggested by the two-step model of cellular cancer initiation and tumor promotion (7). Numerous ingredients, especially tensides and etheric oils, are candidates for tumor promoters because of their property to irritate skin, eyes and mucous tissue of mammals. The suitability of the PTG test to detect such irritants and to predict their potential of irritation has been documented by the screening of many surface-active compounds. Anionic, nonionic and amphoteric tensides frequently present in various cosmetic formulations were used to compare toxicity data obtained from the rabbit eye irritation test, the human skin patch assay, the red blood cell and the PTG test $(18,19)$. Rank correlations revealed good agreement between in vitro and in vivo procedures, such as rabbit eye and skin tests $(18,19)$. Moreover, validation studies on alternatives to the Draize eye irritation assay have shown that the PTG test is among the best suited in vitro methods for risk assessment of cosmetic formulations $(15,16,17)$.

There are some advantages of the PTG test in comparison to assays using mammalian cell lines. The most important one is that pollen tubes do not need amino acids and proteins in their growth medium. Extracellular proteins often interact with many chemicals, thus leading to an overestimation of human toxicity. Another advantage is the deep-freezing tolerance of dry pollen. The pollen grains can be stored in a temperature range from -10 to $-80^{\circ} \mathrm{C}$ without loss of viability and sensitivity to toxic compounds. Moreover, the culture medium is very simple, and photometric quantification of pollen tube growth is quick and easy. Last but not least, no sterile conditions are necessary for pollen tube growth in the culture medium.

Two of the tested mouthwashes (Signal and Thera-med liquid) contain lauryl sulfate detergents, which were shown to strongly irritate the rabbit eye, cause hemolysis and inhibit pollen tube growth to $50 \%$ at concentrations around $7 \mathrm{mg} / \mathrm{L}$ (18). However, the concentrations of this detergent are not declared by the manufacturers of both brands. Other detergents frequently present in mouthwashes are PEG-30 or PEG-40, often used in combination with hydrogenated castor oil. The latter detergent formulation appears to be non-irritating as well as non-inhibitory in the PTG test (18).

It has been shown that, during the test procedure, the plasma membrane of the pollen tube tip is almost directly exposed to the environment because the cell wall of the tip region is highly permeable to water- and lipid-soluble substances. Consequently, it is very sensitive to compounds that interfere with the lipid bilayer of biomembranes (20). It is likely that surfactant-induced irritations of eyes, skin and mucous cell layers are also attributable to major alterations of the plasma membranes of epithelial cells. Therefore, it is not surprising that the toxicity data obtained from the PTG test and Draize assay show such good agreement for tensides and cosmetic formulations.

It is difficult and speculative to transform the interpretations obtained from an in vitro model to in vivo situations. Therefore, one should be very careful in the attempt to predict risk of oral squamous cell irritation from the results of the PTG test. However, the growth inhibition data of this study which, for the first time, 
considered recommended user dilutions of mouthwashes, do not point to a risk of acute irritation. From this point of view, the results of the present investigation could be valuable for human conditions.

\section{RESUMO}

Este estudo investigou se soluções de bochecho nas diluições recomendadas pelos fabricantes podem contribuir para a irritação das mucosas orais. Vinte soluções de bochecho frequentemente utilizadas foram avaliadas por meio do análise do crescimento do tubo polínico. Este teste constitui um método alternativo in vitro para estimar o potencial irritante dos ingredientes de formulações cosméticas. O teste baseia-se numa medição fotométrica da inibição do crescimento de tubos polínicos. A inibição do crescimento é expressa por valores $\mathrm{IC}_{50}$ que caracterizam o potencial citotóxico de uma dada substância. Os valores de $\mathrm{IC}_{50}$ aqui apresentados demonstraram que nenhuma das soluções de bochecho estudadas deve causar irritação aguda das mucosas orais, desde que utilizadas nas diluições recomendadas pelo fabricante. No entanto, verificouse que pelo menos quatro dos colutórios podem causar irritação aguda das mucosas orais ao serem utilizados na a forma concentrada.

\section{ACKNOWLEDGEMENTS}

This study was supported by a grant-in-aid from the Hamburger Stiftung zur Förderung der Krebsbekämpfung (project no. 121).

\section{REFERENCES}

1. Wynder EL, Kabat G, Rosenberg S, Levenstein M. Oral cancer and mouthwash use. J Natl Cancer Inst 1983;70:255-260.

2. Moghadam BK, Gier R, Thurlow T. Extensive oral mucosal ulceration caused by misuse of a commercial mouthwash. Cutis 1999:64:131-134.

3. Kuyama K, Yamamoto H. A study of effects of mouthwash on the human oral mucosae: with special references to sites, sex differences and smoking. J Nihon Univ Sch Dent 1997;39: 202-210.

4. DeMarini DM. Genotoxicity of tobacco smoke and tobacco smoke condensate. Mutation Res 1983:114;59-89.

5. Steele RH, Payne VM, Fulp CW, Rees DC, Lee CK, Doolittle DJ. A comparison of the mutagenicity of mainstream cigarette smoke condensates from a representative sample of the U.S. cigarette market with a Kentucky reference cigarette (K1R4F). Mutation Res 1995;342:179-190.

6. Smigel K. High alcohol mouthwashes are under scrutiny. J Natl Cancer Inst 1991;83:751-756.

7. Mondal S, Heidelberger, Brankow DW. Two-stage chemical oncogenesis in cultures of $\mathrm{C} 3 \mathrm{H} / 10 \mathrm{~T} 1 / 2$ cells. Cancer Res 1976;36:2254-2260.
8. Gagari E, Kabani S. Adverse effects of mouthwash use: a review. Oral Surg Oral Med Oral Pathol 1995;80:432-439.

9. Ossipov NN, Zastavsky BY, Rogozhin S. Action of surfaceactive substances on biological membranes. Colloid Polymer Sci 1978;256:1105-1109.

10. Mashberg A, Barsa P, Grossman ML. A study of the relationship between mouthwash use and oral and pharyngeal cancer. J Am Dent Assoc 1985;110:731-734.

11. Frazier JM, Gad SC, Goldberg AM, McCully JP, Meyer DR. A critical evaluation of alternative tests. In: Goldberg AM (Edtor). A Critical Evaluation of Alternatives to Acute Ocular Irritancy Testing. Alternative Methods in Toxicology, vol. 4. New York: Mary Ann Liebert; 1987. p. 45-75.

12. Friedrich RE, Kristen U. In vitro toxicity assessment of mouthwashes in the pollen tube growth test: first results. Anticancer Res 1999;19:2775-2778.

13. Kristen U, Kappler R. The pollen tube growth test. In: In Vitro Toxicity Testing Protocols. Methods in Molecular Biology. O‘Hare S, Atterwill CK (Editors.). v. 43. Totowa: Humana Press; 1995. p. 189-198.

14. Snedecor GW, Cochran WG. Statistical Methods. Ames: The Iowa State University Press; 1967.

15. Gettings SD, Teal JJ, Bagley DM, Demetrulias JL, DiPasquale LC, Hintze KL, Rozen MG, Weise SL, Chudkowski M, Marenus KD, Pape WJW, Roddy M, Schnetzinger R, Silber PM, Glaza SM, Kurtz PJ. The CTFA evaluation of alternatives program: an evaluation of in vitro alternatives to the Draize primary eye irritation test. (Phase 1) hydro-alcoholic formulations; (Part 2) data analysis and biological significance. In Vitro Toxicol 1991;4:247-288.

16. Gettings SD, DiPasquale LC, Bagley DM, Casterton PL, Chudkowski M, Curren RD, Demetrulias JL, Feder PI, Galli CL, Gay R, Glaza SM, Hintze KL, Janus J, Kurtz PJ, Lordo RA, Marenus KD, Moral J, Muscatiello M, Pape WJW, Renskers KJ, Roddy MT, and Rozen MG. The CTFA evaluation of alternatives program: an evaluation of in vitro alternatives to the Draize primary eye irritation test. (Phase II) oil/water emulsions. Food Chem Toxicol 1994;32:943976.

17. Kristen U, Jung K, Pfannenbecker U, Rensch A, Schell R. Performance of the pollen tube growth test in the COLIPA validation study on alternatives to the rabbit eye irritation test. Toxicol In Vitro 1999;13:335-342.

18. Kristen U, Kappler R, Pape WJW, Hoppe U. In vitro toxicity assessment of tensides: the pollen tube growth test, the red blood cell test and the Draize eye irritation assay in comparison. Bioengineering 1993;9:39-45.

19. Kristen U, Van Aken JP, Pape W, Hoppe U. The pollen tube growth test: use in eye and skin irritancy assessment. In: In Vitro Skin Toxicology, Irritation, Phototoxicity, Sensitization. Alternative Methods in Toxicology. Rougier A, Goldberg AM, Maibach HI (Editors). v. 10. New York: Mary Ann Liebert; 1994. p. 69-77.

20. Rao KS, Kristen U. The influence of the detergent Triton X100 on the growth and ultrastructure of tobacco pollen tubes. Can J Bot 1990;68:1131-1138. 